\title{
PEMETAAN KOMPETENSI LABORATORIUM LINGKUNGAN MELALUI PROGRAM UJI PROFISIENSI LOGAM BERAT DALAM AIR BERSIH
}

\section{MAPPING OF ENVIRONMENTAL LABORATORY COMPETENCY THROUGH PROFICIENCY TESTING PROGRAM FOR HEAVY METAL IN CLEAN WATER}

\author{
Asiah ${ }^{1)}$
}

(Diterima tanggal 5 Juli 2017; Disetujui tanggal 22 September 2017)

\begin{abstract}
ABSTRAK
Peran laboratorium lingkungan sangat dibutuhkan dalam pemantauan lingkungan maupun penegakan hukum lingkungan di seluruh wilayah Indonesia. Namun kenyataannya, 66\% dari sekitar 400 laboratorium yang melakukan pengujian lingkungan terkonsentrasi di pulau Jawa. Sehubungan dengan hal tersebut, perlu dilakukan peningkatan kinerja laboratorium lingkungan sehingga sebaran kompetensi laboratorium merata di seluruh wilayah Indonesia. Salah satu evaluasi kinerja laboratorium dapat dilakukan melalui program uji profisiensi sesuai dengan prinsip ISO/ IEC 17043 dan ISO 13528. Program uji profisiensi diikuti oleh 133 laboratorium binaan Kementerian Lingkungan Hidup dan Kehutanan milik pemerintah provinsi dan kabupaten/kota dengan hasil memuaskan lebih dari $50 \%$ untuk parameter Zn, Fe, dan Cd, sedangkan Mn kurang dari 50\%. Sebaran laboratorium peserta uji profisiesni yang dinyatakan memiliki kompetensi dalam pengujian logam berat terpusat di Pulau Jawa, disusul berturut-turut Pulau Sumatera, Pulau Kalimantan, Pulau Sulawesi dan Pulau Papua. Keberadaan kompetensi laboratorium dengan jumlah lebih besar dari 50\% menunjukkan bahwa laboratorium lingkungan di Indonesia secara umum sudah memiliki kemampuan melakukan analisis logam berat dalam air bersih khusunya parameter $\mathrm{Zn}, \mathrm{Fe}$, dan $\mathrm{Cd}$. Laboratorium tersebut diharapkan dapat mendukung perlindungan dan pengelolaan lingkungan hidup khususnya menghasilkan data yang valid untuk pengujian logam berat dalam air bersih.
\end{abstract}

Kata kunci: uji profisiensi, laboratorium lingkungan, ISO/IEC 17043, ISO 13528

\begin{abstract}
The role of environmental laboratory is needed in environmental monitoring as well as enforcement of environmental law throughout Indonesia. But in fact, $66 \%$ of the about 400 laboratories conducting environmental analysis are concentrated in Java island. Due to this condition, it is necessary to improve the performance of environmental laboratories so that the distribution of laboratory competence is evenly distributed throughout Indonesia. One of the laboratory performance evaluation can be done through the proficiency test program in accordance with the principles of ISO IEC 17043 and ISO 13528. Proficiency testing program is followed by approximately 100 laboratory assisted by the Ministry of Environment and Forestry owned by provincial and district/municipal governments with satisfactory results of more than $50 \%$ for $\mathrm{Zn}, \mathrm{Fe}$, and Cd parameters, whereas Mn is less than $50 \%$. Laboratory distribution of proficiency test participants who are stated to have the competence of heavy metal analysis centered on Java Island, followed by Sumatra Island, Kalimantan Island, Sulawesi Island and Papua Island. The existence of laboratory competence with a number greater than $50 \%$ indicates that environmental laboratories in Indonesia generally have the ability to perform heavy metal analysis in clean water especially parameters of $\mathrm{Zn}, \mathrm{Fe}$, and Cd. The laboratory is expected to support the protection and management of the environment in particular to produce valid data for testing of heavy metals in clean water.
\end{abstract}

Keywords: proficiency test, environmental laboratory, ISO / IEC 17043, ISO 13528

\footnotetext{
1) Puslitbang Kualitas dan Laboratorium Lingkungan KLHK, Kawasan Puspiptek Gd. 210, Jl. Raya Puspiptek-Serpong,

Tangerang Selatan, Banten
} 


\section{PENDAHULUAN}

Keberadaan laboratorium lingkungan sangat penting dan strategis dalam mendukung program perlindungan dan pengelolaan lingkungan hidup sebagaimana diamanahkan dalam Undang - Undang Republik Indonesia No.32 Tahun 2009. Hal ini disebabkan, peran laboratorium lingkungan sangat dibutuhkan dalam pemantauan kualitas lingkungan maupun penegakan hukum lingkungan di seluruh wilayah Indonesia. Jumlah laboratorium yang dapat melakukan pengujian parameter kualitas lingkungan sekitar 400, dari jumlah tersebut hanya 86 laboratorium yang dinyatakan telah memiliki kompetensi dalam melakukan pengujian parameter kualitas lingkungan melalui registrasi Kementerian Lingkungan Hidup dan Kehutanan (KLHK). Enam puluh enam persen (66\%) dari jumlah laboratorium lingkungan tersebut terkonsentrasi di pulau Jawa, sedangkan sisanya tersebar di provinsi, dan kabupaten/kota luar Jawa [1].

Sehubungan dengan hal tersebut, perlu dilakukan peningkatan kinerja laboratorium lingkungan sehingga sebaran kompetensi laboratorium lingkungan merata di seluruh wilayah Indonesia. Salah satu evaluasi kinerja laboratorium lingkungan terkait pengujian parameter kualitas lingkungan dan untuk memantau kinerja secara berkelanjutan dapat dilakukan melalui program uji profisiensi. Penyelenggaraan program uji profisiensi mengikuti kaidah - kaidah ISO/IEC 17043 tentang Conformity Assessment - General Requirementfor Proficiency Testing dan untuk evaluasinya mengacu pada ISO 13528, tentang Statistical Methods for Use in Proficiency Testing by Interlaboratory Comparisons [2-3].
Uji Profisiensi adalah salah satu metode untuk mengetahui unjuk kerja laboratorium dengan cara uji banding antar laboratorium. Uji profisiensitahun 2016 ditujukan bagi laboratorium daerah baik yang belum maupun yang telah diakreditasi berdasarkan ISO/IEC 17025 [4]. Parameter yang digunakan untuk uji profisiensi meliputi antara lain Zn, Fe, Mn, dan $\mathrm{Cd}$ dalam air bersih. Tujuan penyelenggaraan uji profisiensi adalah untuk mengetahui kompetensi laboratorium lingkungan daerah dalam melakukan pengujian parameter logam berat dalam air. Hasil evaluasi uji profisiensi dapat digunakan sebagai kebijakan selanjutnya terkait dengan pemenuhan persyaratan ketelusuran pengujian, peningkatan kapasitas personel laboratorium, dan pemenuhan persyaratan metode standar yang pada akhirnya terakreditasinya laboratorium lingkungan di daerah

\section{METODOLOGI}

Sesuai ISO/IEC 17043, skema uji profisiensi menggunakan skema simultan. Skema simultan dipilih karena paling sesuai penerapan di laboratorium lingkungan daripada skema yang lain. Dalam skema simultan, peserta uji profisiensi dalam rentang waktu yang ditentukan serentak melakukan pengujian terhadap sub sampel yang diambil secara acak dari sumber bahan yang didistribusikan secara simultan kepada seluruh peserta. Apapun skema yang dipilih, penyelanggara wajib membuat perencanaan, penyiapan bahan termasuk uji homogenitas dan uji stabilitas, serta desain statistika evaluasi hasilnya. Bahan uji profisiensi yang didistribusikan 
ke peserta memiliki kisaran kadar dengan mempertimbangkan nilai baku mutu sesuai peraturan perundang -undangan lingkungan hidup yaitu PP 82 tahun 2001 tentang Pengeloaan Kualitas dan Pengendalian Pencemaran Air serta kemampuan peralatan yang dimiliki oleh laboratorium daerah [5]. Parameter dan rentang kadar bahan uji profisiensi ditunjukan sebagaimana Tabel 1, dibawah ini:

Tabel 1: Parameter dan rentang kadar bahan uji profisiensi

\begin{tabular}{ccc}
\hline Parameter & Satuan & Rentang kadar \\
\hline $\mathrm{Zn}$ & $\mathrm{mg} / \mathrm{L}$ & $0,05-2,0$ \\
$\mathrm{Fe}$ & $\mathrm{mg} / \mathrm{L}$ & $0,3-5,0$ \\
$\mathrm{Mn}$ & $\mathrm{mg} / \mathrm{L}$ & $0,1-5,0$ \\
$\mathrm{Cd}$ & $\mathrm{mg} / \mathrm{L}$ & $0,05-2,0$ \\
\hline
\end{tabular}

Pembuatan bahan uji profisiensi dibuat secara volumetrik dengan memperhitungkan estimasi ketidakpastian pengujian. Bahan uji profisiensi dibuat kadar yang cukup kecil degan menggunakan peralatan Spektrofotometer Serapan Atom (SSA) - flame, namun masih diatas nilai limit of quantitation (LoQ) metode berdasarkan ASTM [6-9].

Perhitungan estimasi ketidakpastian mengacu pada ISO/IEC GUIDE 98-3:Guide to the Expression of the Uncertainty in Measurement (GUM) [10]. Sebelum bahan uji profisiensi didistribusikan, uji homogenitas dan uji stabilitas dilakukan oleh penyelenggara untuk menjamin bahwa pada saat bahan uji profisiensi diterima oleh peserta tetap dalam keadaan homogen dan stabil. Uji homogenitas dilakukan pada sejumlah contoh uji yang dipilih secara acak dari botol yang telah diberi nomor. Pengujian dilakukan terhadap masing - masing contoh uji yang terpilih secara duplikat dan selanjutnya dilakukan evaluasi data secara statistika. Contoh uji profisiensi dikatakan homogen apabila:

$$
S S=0,3 \sigma_{S D P A}
$$

dimana:

$$
\begin{aligned}
\sigma_{S D P A}: & \text { Standard Deviation for } \\
& \text { ProficiencyAssessment } \\
& \text { (simpangan baku asesmen } \\
& \text { profisiensi) } \\
\text { Ss } \quad \text { : nilai heterogenitas contoh uji } & \text { profisiensi yang merupakan } \\
& \text { standar deviasi antara seluruh } \\
& \text { contoh uji homogenitas, yang } \\
& \text { dirumuskan sebagai berikut: }
\end{aligned}
$$

$$
S_{S}=\sqrt{S_{x}^{2}-\left(S_{w}^{2} / 2\right)}
$$

dimana:

$\mathrm{S}_{\mathrm{x}}$ : standar deviasi rata - rata contoh uji

$\mathrm{S}_{\mathrm{w}}$ : standar deviasi antar contoh uji simplo dan duplo

Uji stabilitas dilakukan terhadap salah satu dari empat parameter bahan uji profisiensi logam berat dalam air. Hal ini dilakukan karena 4 parameter logam berat tersebut diencerkan dari larutan induk ke dalam satu wadah sehingga dapat diasumsikan bahwa jika salah satu parameter dinyatakan homogen, maka 3 parameter lainnya juga homogen. 3 contoh uji dipilih secara acak dari sejumlah contoh uji pada tahapan uji homogen dan dianalisis secara duplo. Bila nilai mutlak selisih dari rata - rata hasil uji homogenitas dan stabilitas lebih kecil atau sama dengan 0,3 kali SDPA, maka contoh uji dinyatakan stabil:

$$
\left|\bar{y}_{1}-\bar{y}_{2}\right| \leq 0,3 \sigma_{S D P A}
$$

dimana:

$\bar{y}_{1}$ : rata - rata kadar pengujian hasil uji homogenitas 
$\bar{y}_{2}:$ rata - rata kadar pengujian hasil uji stabilitas

Penentuan nilai $\sigma_{S D P A}$ dihitung berdasarkan ISO 13528 dengan menggunakan model umum yang merupakan pendekatan yang dijabarkan oleh Horwitz dan dimodifikasi oleh Thompson. Pendekatan ini merupakan model umum untuk memperoleh standar deviasi reprodusibilitas yang dinyatakan sebagai $\sigma_{R}$ . Nilai $\sigma_{R}$ dihitung sesuai dengan rumusan sebagai berikut:

$$
\sigma_{R}= \begin{cases}0,22[\mathrm{C}] & \text { jika }[\mathrm{C}]<1,2.10^{-7} \\ 0,02[\mathrm{C}]^{0,8495} & \text { jika } 1,2.10^{-7} \leq[\mathrm{C}] \leq 0,138 \\ 0,01[\mathrm{C}]^{0,5} & \text { jika }[\mathrm{C}]>0,138\end{cases}
$$

dimana:

[C] adalah nilai fraksi massa contoh uji (massa/massa).

Setelah evaluasi uji homogenitas dan stabilitas memenuhi kriteria batas keberterimaan statistika, maka bahan uji profisiensi diberi identitas dan didistribusikan kepada para peserta. Nomor identitas bertujuan untuk menjaga independensi dan kerahasiaan hasil uji profisiensi dari peserta lain atau pihak lainnya. Karena itu, nomor identitas peserta hanya diketahui oleh pihak penyelenggara. Pada waktu yang telah ditetapkan oleh penyelenggara, maka hasil pengujian bahan uji profisiensi dari masing-masing peserta disampaikan kepada penyelenggara untuk dievaluasi.

Evaluasi kinerja peserta uji profisiensi menggunakan nilai $\mathrm{Z}_{\text {score }}$ dengan rumus:

$$
Z_{\text {score }}=\frac{x_{i}-x_{\mathbb{P}}}{\sigma_{S D P A}}
$$

dimana:

$$
\begin{aligned}
& x_{i} \text { : nilai hasil pengujian peserta uji } \\
& \text { profisiensi }
\end{aligned}
$$

$$
\begin{aligned}
x_{P T} \quad & \text { nilai kadar bahan uji } \\
& \text { profisiensi yang ditetapkan } \\
& \text { (assigned value) oleh } \\
& \text { penyelenggara berdasarkan } \\
& \text { perhitungan nilai formulasi } \\
& \text { secara volumetrik } \\
\sigma_{S D P A}: & \text { standard deviation for } \\
& \text { proficiency assessment } \\
& \text { (simpangan baku asesmen } \\
& \text { profisiensi) }
\end{aligned}
$$
$\sigma_{S D P A}:$ standard deviation for proficiency assessment (simpangan baku asesmen profisiensi)

Hasil evaluasi kinerja laboratorium peserta uji profisiensi dengan menggunakan perhitungan nilai $\mathrm{Z}_{\text {score }}$ dikelompokkan menjadi tiga kategori, yaitu:

1) memuaskan : hasil pengujian laboratorium peserta terletak pada $\mathrm{Z}_{\text {score }}$ antara -2 dan +2 yang dapat dinotasikan sebagai $\left|Z_{\text {score }}\right| \leq 2$;

2) diperingatkan : hasil pengujian laboratorium peserta terletak pada $\mathrm{Z}_{\text {score }}$ antara -3 dan -2 atau antara +2 dan +3 yang dapat dinotasikan sebagai $2<\left|Z_{\text {score }}\right|<$ 3. Bagi peserta yang memiliki nilai $Z_{\text {score }}$ diberi tanda ( $\$$ );

3) tidak memuaskan: hasil pengujian laboratorium peserta terletak pada $\mathrm{Z}_{\text {score }}$ kurang dari -3 atau lebih dari +3 yang dapat dinotasikan sebagai $\left|Z_{\text {score }}\right| \geq 3$. Jika peserta yang memiliki nilai $\mathrm{Z}_{\text {score }}$ diberi tanda $(\$ \$)$. 


\section{HASIL DAN PEMBAHASAN}

Bahan uji profisiensi terdiri dari 4 parameter logam berat yaitu $\mathrm{Mn}, \mathrm{Fe}, \mathrm{Cd}$ dan $\mathrm{Zn}$ dalam air memiliki kelarutan yang sama, maka uji homogenitas dan uji stabilitas diwakili salah satu logam berat yaitu Fe dengan hasil sebagaimana disajikan dalam Tabel 2 dibawah ini:

Bahan uji profisiensi telah dinyatakan homogen dan stabil sampai saat dilakukan dianalisis oleh peserta. Uji homogenitas dan stabilitas dapat mengurangi heterogenitas sampel antar laboratorium peserta serta terjadinya bias hasil uji profisiensi.

Dalam waktu yang telah ditentukan, seluruh laboratorium peserta harus melakukan pengujian bahan uji profisiensi dan hasilnya dikirim ke penyenggara. Data hasil uji profisiensi yang diterima oleh penyelenggara dilakukan analisis data untuk mengetahui adanya data ekstrim yaitu suatu data yang dilaporkan tidak sesuai dengan aturan yang yang ditetapkan oleh pihak penyelenggara misalnya: kesalahan pencantuman satuan, melaporakan nilai kurang dari atau lebih dari atau kesalahan desimal. Data ekstrim dianggap sebagai data pencilan dari suatu populasi data yang ada. Data ekstrem tidak dievaluasi lebih lanjut, sedangkan terhadap data hasil uji profisiensi yang memenuhi analisis data dievaluasi menggunakan statistik $\mathrm{Z}_{\text {score }}$ sebagaimana rumus (5). Nilai $\mathrm{Z}_{\text {score }}$ ditentukan dengan mempertimbangkan nilai yang ditetapkan (assign value) saat pembuatan bahan uji profissiensi secara spesifik atau rumusan formulasi, sedangkan nilai SDPA ditentukan dengan rumusan Horwitz value sebagaimana persamaan (4). Assign value beserta SDPA disajikan dalam Tabel 2.

Tabel 2 : Uji Homogenitas dan uji stabilitas Fe

\begin{tabular}{|c|c|c|c|c|c|c|c|c|}
\hline No Uji & No & Konsentrasi & $\mathrm{g} / \mathrm{L})$ & & & & & \\
\hline & Contoh Uji & $\mathrm{x}_{1}$ & $\mathrm{x}_{2}$ & $x_{t}$ & $x_{t}-x_{r}$ & $\left(x_{t}-x_{r^{2}}\right.$ & $\mathrm{w}_{\mathrm{t}}$ & $w_{t}$ \\
\hline 1 & 17 & 0.2940 & 0.2957 & 0.29 & 0.001 & 0.00000 & 0.00170 & 0.00000 \\
\hline 2 & 18 & 0.2936 & 0.2947 & 0.29 & 0.000 & 0.00000 & 0.00110 & 0.00000 \\
\hline 3 & 20 & 0.2942 & 0.2938 & 0.29 & 0.000 & 0.00000 & 0.00040 & 0.00000 \\
\hline 4 & 27 & 0.2947 & 0.2917 & 0.29 & -0.001 & 0.00000 & 0.00300 & 0.00001 \\
\hline 5 & 45 & 0.2932 & 0.2943 & 0.29 & 0.000 & 0.00000 & 0.00110 & 0.00000 \\
\hline 6 & 64 & 0.2957 & 0.2934 & 0.29 & 0.000 & 0.00000 & 0.00230 & 0.00001 \\
\hline 7 & 85 & 0.2965 & 0.2953 & 0.30 & 0.002 & 0.00000 & 0.00120 & 0.00000 \\
\hline 8 & 116 & 0.2926 & 0.2940 & 0.29 & -0.001 & 0.00000 & 0.00140 & 0.00000 \\
\hline 9 & 168 & 0.2934 & 0.2930 & 0.29 & -0.001 & 0.00000 & 0.00040 & 0.00000 \\
\hline 10 & 192 & 0.2950 & 0.2952 & 0.30 & 0.001 & 0.00000 & 0.00017 & 0.00000 \\
\hline \begin{tabular}{|l|} 
Jumlah \\
\end{tabular} & & & & & & 0.000007 & & 0.000023 \\
\hline Rata-rata & & & & 0.2942 & $\begin{array}{c}\mathrm{Sx} \\
\mathrm{Sx}^{2}\end{array}$ & $\begin{array}{c}0.0009 \\
0.000001\end{array}$ & $\begin{array}{c}\mathrm{Sw} \\
\mathrm{Sw}^{2} \\
\mathrm{Ss}\end{array}$ & $\begin{array}{c}0.0011 \\
0.000001 \\
0.000902\end{array}$ \\
\hline SDPA & & 0.0050 & & $\mathrm{w}_{\mathrm{t}}=$ betwee & $n$ test portion $r$ & & & \\
\hline 0,3 ó & & 0.0015 & & $\mathrm{x}_{\mathrm{t}}=$ sample & averages & & & \\
\hline Syarat Ke & terimaan & $\mathrm{Ss}<0,30$ ́ & & $\mathrm{xr}=$ gener & l averages & & & \\
\hline Kesimp & n : bahan u & homogen & & & & & & \\
\hline Rata-rata & $\begin{array}{l}\text { Homogenitas } \\
\mathrm{Xr} \text { ) }\end{array}$ & $\begin{array}{l}\text { Rata-rata Uji } \\
\text { Stabilitas (Yr) }\end{array}$ & $\mathrm{Xr}-\mathrm{Yr}$ & SDPA (ó) & Kriteria & & mpulan & \\
\hline & 2942 & 0.293 & 0.0016 & 0.0050 & Xr-Yr? 0,3ó & & uji stabi & \\
\hline
\end{tabular}


Tabel 3. Nilai assign value dan SDPA bahan uji profisiensi

\begin{tabular}{cccc}
\hline Parameter & Satuan & Assign value & $\delta_{\text {SDPA }}$ \\
\hline $\mathrm{Zn}$ & $\mathrm{mg} / \mathrm{L}$ & $0,060 \pm 0,001$ & 0,015 \\
$\mathrm{Fe}$ & $\mathrm{mg} / \mathrm{L}$ & $0,301 \pm 0,004$ & 0,058 \\
$\mathrm{Mn}$ & $\mathrm{mg} / \mathrm{L}$ & $0,120 \pm 0,001$ & 0,026 \\
$\mathrm{Cd}$ & $\mathrm{mg} / \mathrm{L}$ & $0,060 \pm 0,001$ & 0,015 \\
\hline
\end{tabular}

Hasil evaluasi uji profisiensi per-parameter dapat diuraikan sebagai berikut:

\section{a. Parameter $\mathrm{Zn}$}

Uji profisiensi paremeter Zn dalam air bersih diikuti oleh 104 laboratorium peserta dengan hasil pengujian digambarkan secara histogram segaimana Gambar 1. Jika menggunakan batasan range of toleransi $\mathrm{Z}_{\text {score }}$ yaitu $-2 \leq \mathrm{Z}_{\text {score }}$ $\leq 2$ untuk kadar $\mathrm{Zn}=0,060 \mathrm{mg} / \mathrm{L}$, maka diperoleh kisaran kadar 0,034 mg/L - 0,086 mg/L. Berdasarkan batasan tersebut, maka laboratorium peserta yang
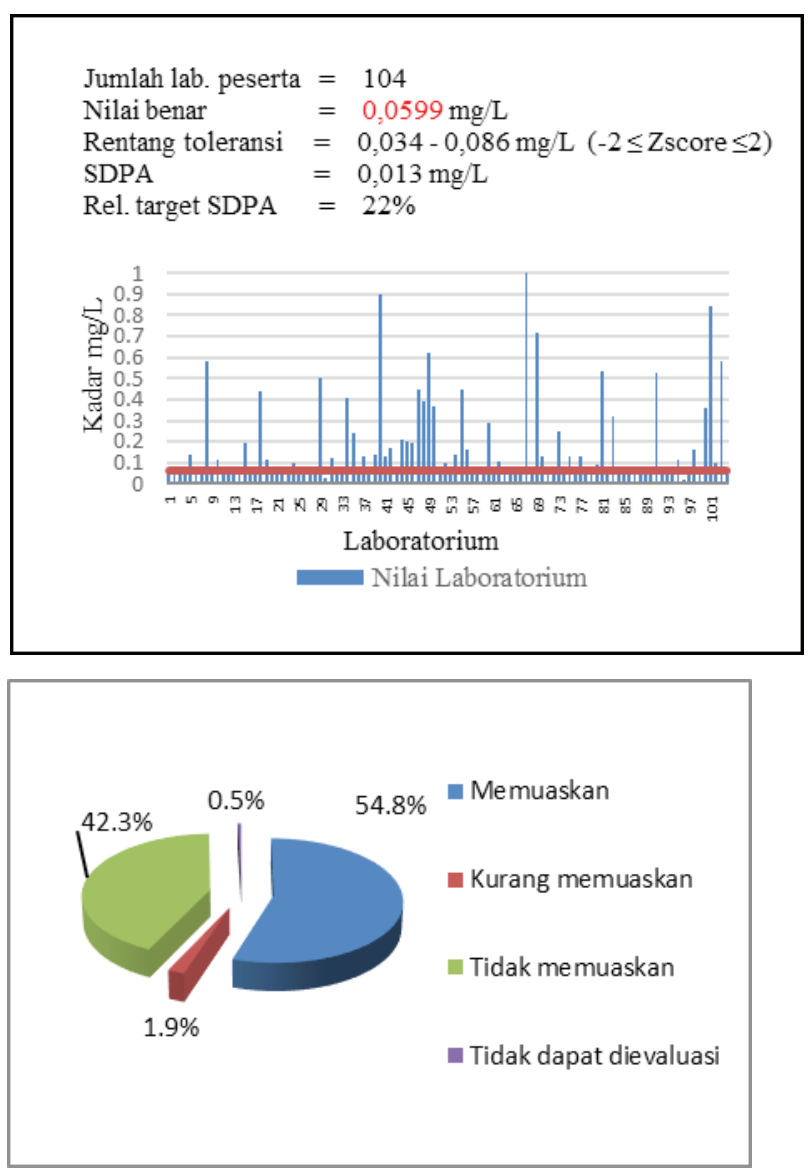

Gambar 1. Histogram dan prosentase hasil uji profisiensi Zn dalam air mempunyai kriteria hasil memuaskan melakukan pengujian $\mathrm{Zn}$ dalam air bersih sebanyak $54,8 \%$ atau 57 laboratorium. Sedangkan sebanyak 42,3\% laboratorium peserta dinyatakan tidak memuaskan atau tidak memiliki kompetensi untuk melakukan pengujian $\mathrm{Zn}$ dalam air bersih.

\section{b. Parameter Fe}

Jika menggunakan batasan range of toleransi parameter Fe pada kadar 0,301 $\mathrm{mg} / \mathrm{L}$, maka diperoleh kisaran kadar 0,186 mg/L - 0,416 mg/L. Dengan demikian, dapat disimpulkan bahwa laboratorium peserta yang mempunyai nilai memuaskan melakukan pengujian Fe dalam air bersih sebanyak $62,4 \%$ atau 83 laboratorium. Sebanyak 28,6\% atau 38 laboratorium peserta dinyatakan tidak memiliki kompetensi untuk melakukan pengujian Fe. Penyelenggaraan uji profisiensi paremeter Fe dalam air bersih ini diikuti oleh 133 laboratorium peserta.

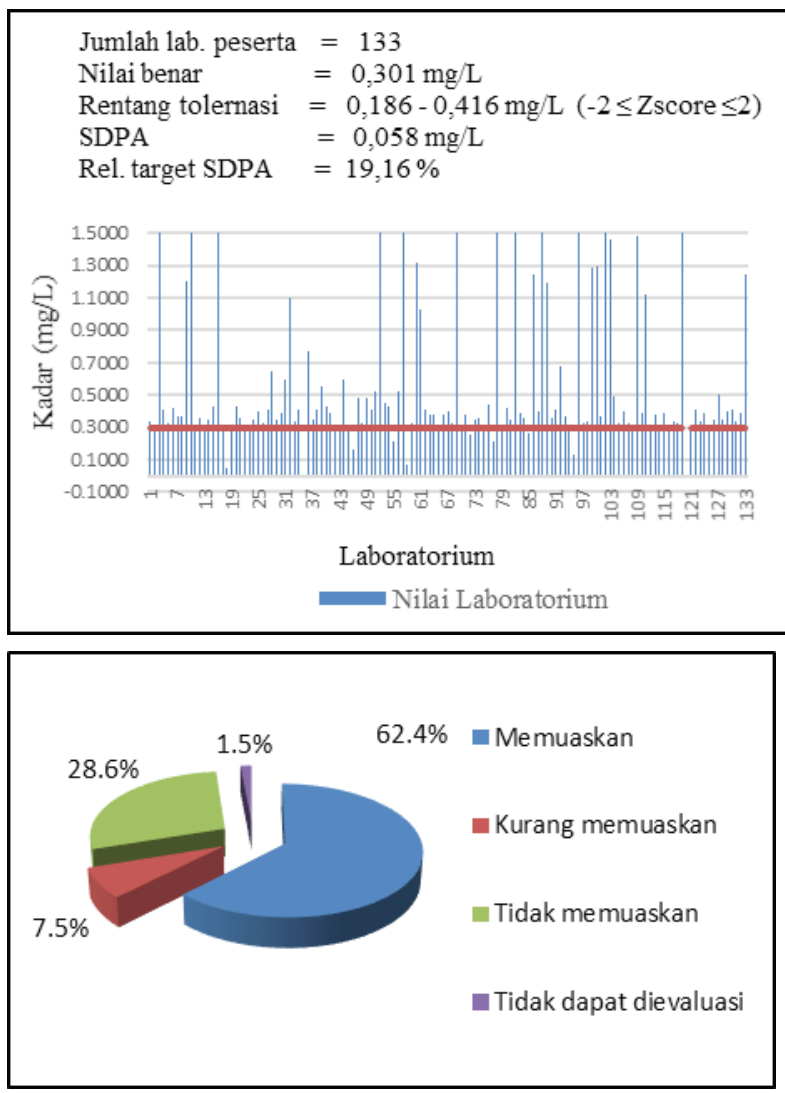

Gambar 2. Histogram dan prosentase hasil uji profisiensi Fe dalam air 


\section{c. Parameter Mn}

Seratus sebelas (111) laboratorium peserta dari kabupaten dan kota telah mengikuti program uji profisiensi paremeter Mn dalam air bersih dengan hasil sebagaimana Gambar 3. Dengan menggunakan batasan range of toleransi atau $-2 \leq \mathrm{Z}_{\text {score }} \leq 2$, maka kisaran kadar diperoleh 0,067 mg/L - 0,173 mg/L untuk kadar $\mathrm{Mn}=0,120 \mathrm{mg} / \mathrm{L}$. Berdasarkan batasan evaluasi tersebut, maka laboratorium peserta, yang mempunyai nilai memuaskan atau yang memiliki kompetensi melakukan pengujian Mn dalam air bersih sebanyak 49,5\% atau 55 laboratorium. Sedangkan sejumlah $40,5 \%$ atau 45 laboratorium peserta dinyatakan tidak memuaskan atau tidak memiliki kompetensi untuk melakukan pengujian $\mathrm{Zn}$ dalam air bersih.

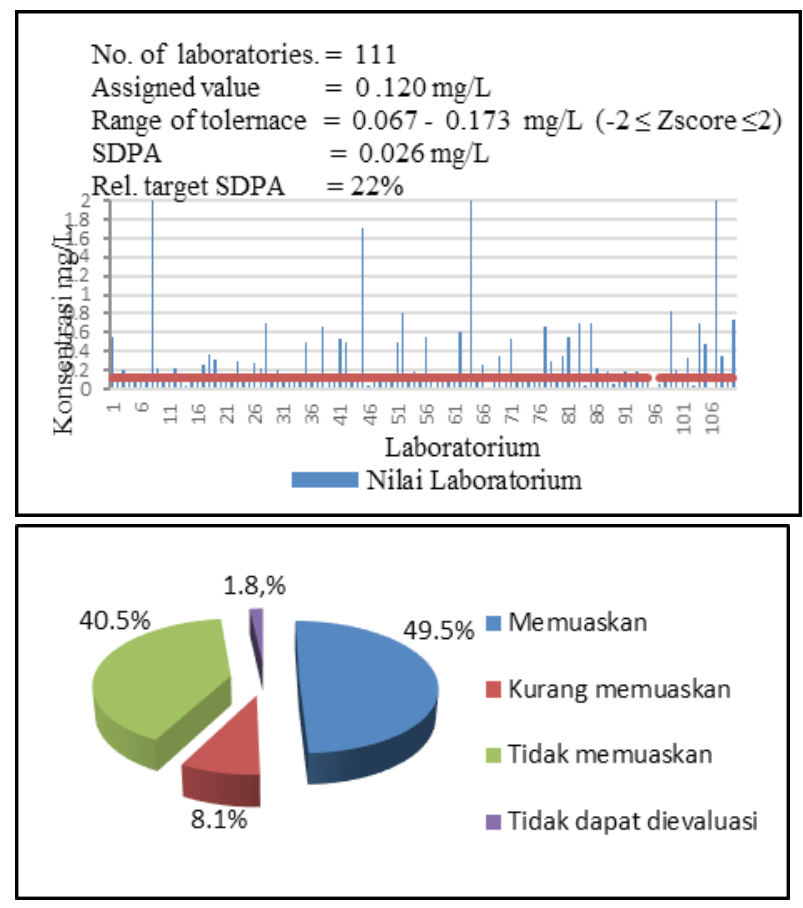

Gambar 3. Histogram dan prosentase hasil uji profisiensi Mn dalam air

\section{d. Parameter Cd}

Uji profisiensi parameter $\mathrm{Cd}$ dalam air bersih dengan kadar $0,06 \mathrm{mg} / \mathrm{L}$ telah diikuti oleh 83 laboratorium peserta dari kabupaten dan kota. Berdasarkan nilai kadar tersebut maka rentang kadar 0,034 mg/L - 0,087 mg/L digunakan sebagai batasan range of toleransi atau 2 $\leq \mathrm{Z}_{\text {score }} \leq 2$. Jumlah laboratorium peserta yang mempunyai nilai memuaskan atau yang memiliki kompetensi melakukan pengujian $\mathrm{Cd}$ dalam air bersih sebanyak $78 \%$ atau 65 laboratorium. Sebanyak 16\% atau 13 laboratorium peserta dinyatakan tidak memuaskan atau tidak memiliki kompetensi untuk melakukan pengujian $\mathrm{Cd}$ dalam air bersih. Histogram data hasil pengujian uji profisiensi seluruh laboratorium peserta sebagaimana Gambar 4.

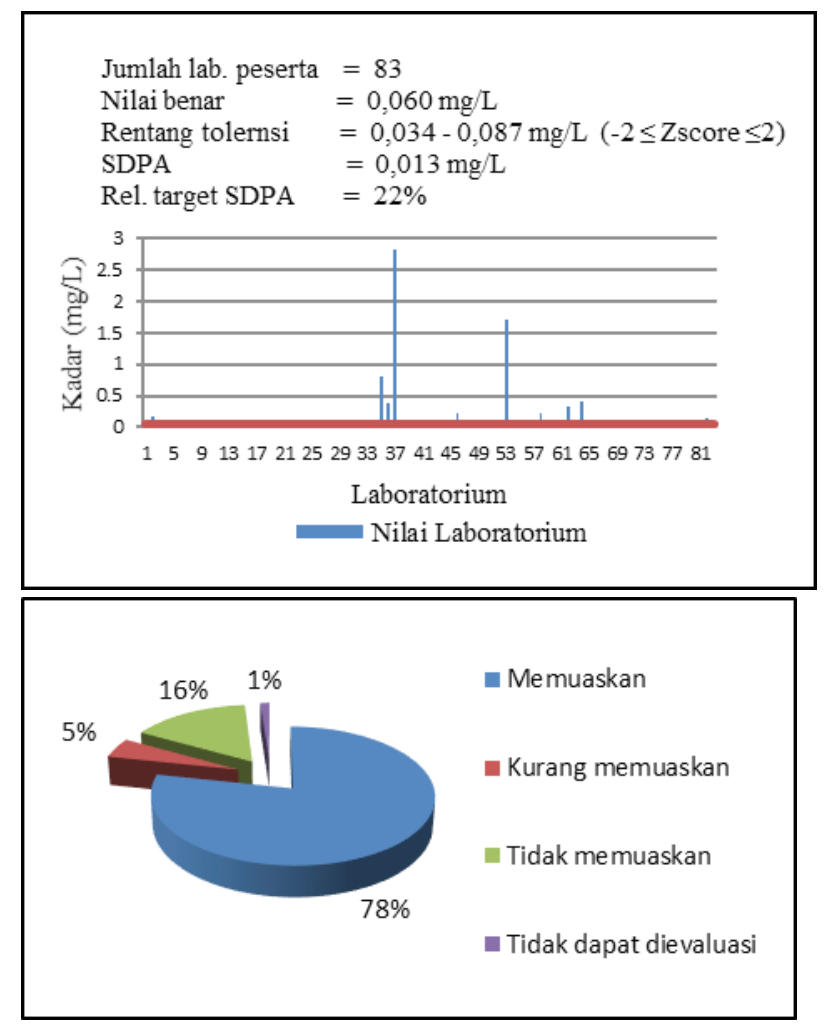

Gambar 4. Histogram dan prosentase hasil uji profisiensi $\mathrm{Cd}$ dalam air

Sebaran kompetensi laboratorium berdasarkan hasil uji profisiensi untuk 4 parameter logam berat, $\mathrm{Mn}, \mathrm{Fe}, \mathrm{Cd}$ dan $\mathrm{Zn}$ dalam air yang diikuti oleh laboratorium kabupaten/kota seluruh Indonesia diilustrasikan seperti pada Gambar 5. Berdasarkan ilustrasi tersebut, 


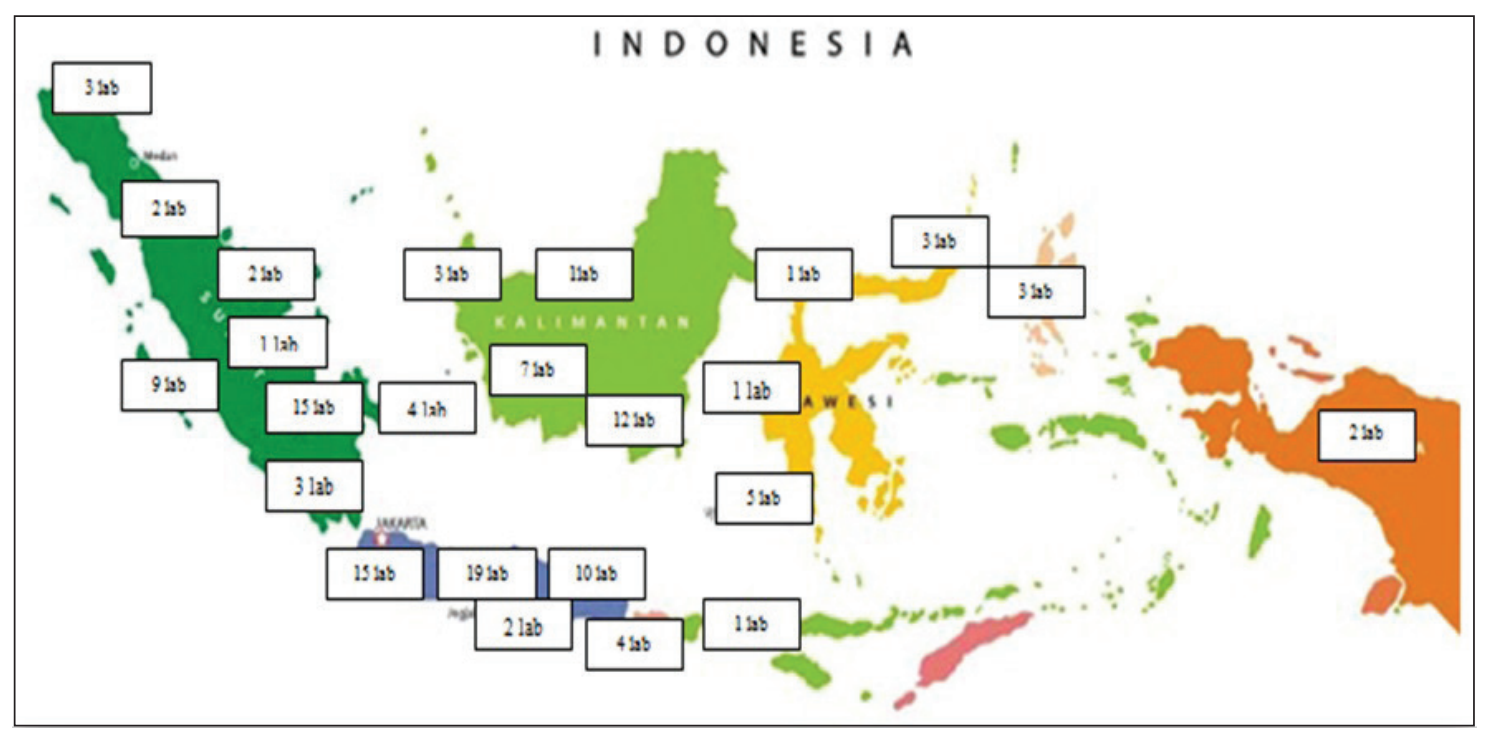

Gambar 5. Pemetaan jumlah kompetensi laboratorium melalui uji profisiensi logam berat dalam air

jumlah laboratorium yang kompeten melakukan pengujian parameter logam dalam air terpusat di Pulau Jawa, kemudian disusul berturut - turut Pulau Sumatera, Kalimantan, Sulawesi dan Papua.

Sehubungan dengan banyaknya hasil uji profisiensi laboratorium peserta yang tidak dapat dievaluasi lebih lanjut dan tidak memuaskan, maka perlu dilakukan identifikasi akarpenyebab permasalahan diantaranya adalah pada proses pengenceran bahan uji profisiensi dimungkinkan menggunakan peralatan gelas volumetrik yang tidak terkalibrasi sehingga tidak laik pakai, metode pengujian yang digunakan belum divalidasi atau diverifikasi sebagaimana mestinya, kurangnya kompetensi personel dalam melakukan pengujian logam berat, ketidaklaikan pakai peralatan Atomic Absorption Spectrophotometer (AAS) atau spectrophotometer UV-Vis, pembuatan kurva kalibrasi yang tidak memenuhi kaidah ilmiah, serta lemahnya verifikasi dan validasi data hasil pengujian saat pelaporan [11]. Sehubungan dengan hal tersebut, untuk menghasilkan data pengujian yang valid, maka batasan kriteria keberterimaan pengendalian mutu internal harus dipenuhi sebelum pelaporan hasil ke penyelenggara.

Pengendalian mutu internal yang harus dipertimbangkan saat pelaporan hasil uji profisiensi adalah:

1) personel laboratorium yang melakukan pengujian bahan uji profisiensi harus memiliki kompetensi dengan dibuktikan hasil intra-laboratory correlation atau analyst proficiency test untuk parameter logam berat $\mathrm{Mn}, \mathrm{Fe}, \mathrm{Cd}$ dan $\mathrm{Zn}$ dalam air bersih dengan menggunakan peralatan AAS;

2) metode pengujian logam berat $\mathrm{Mn}, \mathrm{Fe}, \mathrm{Cd}$ dan $\mathrm{Zn}$ dalam air bersih telah divalidasi atau diverifikasi sebagaimana mestinya sehingga memenuhi persyaratan dan sesuai tujuan yang ditetapkan;

3) hasil kalibrasi peralatan gelas volumetrik yang digunakan untuk pengenceran bahan uji profisiensi harus tertelusur ke sistem satuan internasional memenuhi batas keberterimaan yaitu jumlah ketidakpastian 
dan koreksi kurang dari toleransi peralatan gelas;

4) instrumentasiAAS atau spectrophotometer $U V$-Vis yang digunakan untuk pengujian bahan uji profisiensi harus dikalibrasi dan/atau uji kinerja khususnya uji akurasi panjang gelombang dan sensitifitas absorbansi memenuhi batas keberterimaan yang ditetapkan oleh pabrikan pembuat instrumen tersebut;

5) pembuatan kurva kalibrasi harus memenuhi kaidah ilmiah yaitu:

a. deret larutan kerja terdiri dari 1 (satu) blanko dan minimal 3 (tiga) kadar yang berbeda secara proporsional dimana deret larutan kerja terendah adalah limit of quantitation (LoQ) metode sedangkan deret larutan kerja tertinggi sekitar 2 kali kadar bahan uji profisiensi. Gunakan bahan kimia berkualitas murni (pro-analysis) dengan air demineralisasi yang memiliki konduktivitas $<1 \mu \mathrm{S} / \mathrm{cm}[12]$.

b. jika koefisien korelasi regreasi linier (r) $<0,995$, periksa kondisi instrumen dan ulangi pembuatan kurva kalibrasi hingga diperoleh nilai $(r) \geq 0,995$ [13];

c. bila nilai intersep pada persamaan regresi linear yang terbentuk $>$ method detection limit (MDL), maka ulangi pembuatan kurva kalibrasi hingga diperoleh nilai intersep $\leq$ MDL;

d. periksa nilai tengah kurva kalibrasi dengan melakukan pembacaan deret larutan kerja yang independen (laboratory control standard, LCS) hingga menghasilkan $\% \mathrm{R}_{\mathrm{LCS}}=100 \% \pm$ $5 \%$ [14].

6) hasil pengujian blanko sebagai kontrol kontaminan harus kurang MDL;
7) lakukan analisis duplo untuk uji presisi terhadap bahan uji profisiensi dengan hasil \%RPD $\leq 10 \%$ dan lakukan kontrol akurasi dengan spike matrix hingga hasil $\% \mathrm{R}=100 \% \pm 10 \%[15]$

\section{SIMPULAN}

Uji profisiensi diikuti oleh laboratorium binaan Kementerian Lingkungan Hidup dan Kehutanan (KLHK) milik pemerintah provinsi dan kabupaten/kota dengan hasil memuaskan lebih dari 50\% untuk parameter $\mathrm{Zn}, \mathrm{Fe}$, dan $\mathrm{Cd}$, sedangkan Mn kurang dari 50\%. Sebaran laboratorium peserta uji profisiesni yang dinyatakan memiliki kompetensi pengujian parameter logam berat terpusat di Pulau Jawa, disusul berturut - turut Pulau Sumatera, Pulau Kalimantan, Pulau Sulawesi dan Pulau Papua. Keberadaan kompetensi laboratorium dengan jumlah lebih besar dari 50\% menunjukkan bahwa laboratorium lingkungan di Indonesia secara umum sudah memiliki kemampuan melakukan analisis logam berat dalam air khusunya parameter $\mathrm{Zn}$, $\mathrm{Fe}$, dan Cd. Keberadaan laboratorium tersebut diharapkan dapat mendukung perlindungan dan pengelolaan lingkungan hidup khususnya menghasilkan data yang valid pengujian logam berat dalam air bersih.

\section{UCAPAN TERIMAKASIH}

Dalam kesempatan ini penulis mengucapkan terimakasih kepada semua pihak khususnya Bidang Metrologi, Laboratorium P3KLL dan laboratorium peserta yang telah berpatisipasi dalam uji profisiensi logam berat dalam air bersih. 


\section{DAFTAR PUSTAKA:}

(1) http://www.menlh.go.id/daftarlembaga-penyedia-jasa-lingkunganyang-teregistrasi-ii, diunduh tanggal 5 Mei 2017

(2) International Standards for Organization/International Electrotechnical Commission (ISO/ IEC) $17043: 2008$ Conformity Assessment - General Requirements for Proficiency Testing;

(3) International Standards for Organization (ISO) $13528: 2015$ Statistical Methods For use In Proficiency Testing By Interlaboratory Comparisons;

(4) International Standards for Organization/International Electrotechnical Commission (ISO/IEC) 17025, 2005, General Requirements for the Competence of Calibration and Testing Laboratories, ISO, Switzerland;

(5) Kementerian Negara Lingkungan Hidup. 2001. Peraturan Pemerintah Nomor 82 tahun 2001 tentang Pengeloaan Kualitas dan Pengendalian Pemcemaran Air, Jakarta;

(6) American Standard Testing and Material (ASTM) D 35557: 2017 Standard Test Methods for Cadmium in Water;

(7) American Standard Testing and Material (ASTM) D 858: 2017 Standard Test Methods for Manganese in Water;

(8) American Standard Testing and Material (ASTM) D 1068: 2015 Standard Test Methods for Iron in Water;
(9) American Standard Testing and Material (ASTM) D 1691: 2017 Standard Test Methods for Zink in Water;

(10) ISO/IEC Guide 98-3 : 2008 Uncertaninty of Measurement Part 3 : Guide to the expression of uncertainty in measurement;

(11) http://www.chem.science.unideb. hu/Pharm/FAAS.pdf. Flame atomic absorbtion spectroscopy (FAAS), diunduh tanggal 2 Juni 2017

(12) Hadi Anwar, 2000, "Sistem Manajemen Mutu Laboratorium Sesuai ISO/IEC 17025 : 2005 General Requirements For The Competence Of Calibration and Testing Laboratories", PT. Gramedia Pustaka Utama, Jakarta;

(13) Standard Methods for the Examination of Water and Wastewater, 22 $2^{\text {ndt }}$ Edition, 2012, American Public Health Association, Washington DC USA;

(14) http://faculty.sdmiramar.edu/fgarces/ LabMatters/Instruments/AA/AAS Theory/AASTheory.htm. Principle of Atomic Absorption/Emission Spectroscopy, diunduh tanggal $30 \mathrm{Mei}$ 2017;

(15) h t t p : / / w w w a p g q a.co m / newsletters/12_2003_calibration. asp. Back to the Basics The Importance of a Good Calibration, diunduh tanggal 17 Mei 2017; 